\title{
Europejska Agencja Kosmiczna (ESA) - ambitne plany, skromne możliwości, potężni konkurenci
}

Projekty kosmiczne, realizowane przez czołowe mocarstwa świata, są oczywistym wyznacznikiem nowoczesności i siły ich gospodarek, a także ich prestiżu. Podczas „zimnej wojny” o prymat w kosmosie rywalizowały USA i ZSRR, obecne aspiracje Chin do roli globalnego mocarstwa również są uzupełniane wyprawami kosmiczny$\mathrm{mi}^{1}$. Własne aspiracje kosmiczne mają też państwa Unii Europejskiej, a także - sama UE. Trzeba jednak zauważyć odmienny charakter tych projektów: o ile wielkie mocarstwa, zarówno w czasie „zimnej wojny”, jak i obecnie wiązały swoją eksplorację kosmosu z podnoszeniem potencjału militarnego - o tyle UE preferuje raczej pokojową penetrację przestrzeni kosmicznej, służącą bardziej nauce i działalności gospodarczej niż obronności (ale nie pozbawioną aspiracji politycznych, mającą uwydatniać unijną „soft power").

Tematem niniejszego artykułu jest przybliżenie struktury, potencjału i obszarów aktywności Europejskiej Agencji Kosmicznej. Nie negując słabości tej organizacji w porównaniu z podobnymi agencjami czołowych mocarstw (USA, Chin czy Rosji) pamiętać należy, że jest to agencja wielonarodowa, której aktywność (tak jak UE) jest ograniczona przez suwerenność państw członkowskich. Podstawowymi pytaniami badawczymi tekstu są:

- kwestia potencjału i zasobów Agencji - zwłaszcza w porównaniu z jej głównymi konkurentami

- kwestia zdolności Agencji do prowadzenia samodzielnych, rozbudowanych misji w kosmosie

- kwestia perspektyw rozwoju Agencji

$\mathrm{W}$ połowie lat 50-tych wyścig $\mathrm{w}$ kosmosie prowadziły dwa supermocarstwa: USA i ZSRR. W porównaniu $\mathrm{z}$ ich zasobami i zaawansowaniem technologicznym możliwości państw zachodnioeuropejskich były niezwykle skromne (d'Antonio, 2012, s. 44-47)2. Jednak postępy integracji europejskiej (powstanie EWWiS w 1952 r., EWG

${ }^{1}$ Ciekawostką jest, że Chińczycy starają się też wprowadzić własne nazewnictwo: ugruntowane już w okresie rywalizacji amerykańsko-sowieckiej określenia ,astronauta” i „kosmonauta” uzupełniają własnym ,taikonauta”.

${ }^{2}$ Aczkolwiek należy pamiętać np. o niemieckich osiągnięciach naukowych z czasów II wojny światowej. Hitlerowskie pociski „V-1” i „V-2” były niezwykle groźną bronią, ich konstruktor Wernher von Braun (1912-1977) po upadku III Rzeszy przeszedł na służbę Amerykanów i był czołową postacią projektów kosmicznych USA. 
i EWEA w 1957 r.), zachęcały do nawiązania europejskiej współpracy również w zakresie badań kosmicznych.

W 1958 r. państwa zachodnioeuropejskie rozpoczęły debatę na temat powołania własnej agencji kosmicznej. Ostatecznie zdecydowano o utworzeniu dwóch odrębnych struktur:

- Europejskiej Organizacji Rozwoju Rakiet Nośnych (ang. European Launcher Development Organisation, ELDO),

- Europejskiej Organizacji Badań Kosmicznych (ang. European Space Research Organization, ESRO), mającej zajmować się badaniami przestrzeni kosmicznej i budową aparatury i satelitów naukowych,

ELDO powstawała od 1961 r., początkowo jako porozumienie brytyjsko-francuskie, a ukonstytuowała się formalnie w 1964 r. jako grupa 6 państw zachodnioeuropejskich i Australii (zob. tab. 1). Podstawowym celem ELDO było opracowanie trójstopniowej rakiety nośnej „Europa”. O ile pierwszy człon był już w zasadzie zbudowany (brytyjska rakieta „Blue Streak”), to II człon miała stanowić francuska rakieta „Coralie”, a III człon byłby produktem niemieckim „Astris”, Włochy miały zaprojektować satelitę, a Belgia i Holandia - opracować system śledzenia i telemetrii. Program zakończył się w 1971 r. spektakularnym fiaskiem - o ile segment brytyjski w zasadzie był bezawaryjny, o tyle żadna próba z kolejnymi stopniami nie przyniosła sukcesu. Testy prowadzono początkowo na australijskim poligonie rakietowym Woomera, później przeniesiono je na kosmodrom Kourou w Gujanie Francuskiej. Po wygaszeniu programu „Europa””, przystąpiono do francuskiego projektu rakiet nośnych „Ariane”.

Z kolei w latach 1962-1964 powstała ESRO, która zajmowała się badaniami przestrzeni kosmicznej i astronautyką. Jej członkami było 10 państw Europy Zachodniej (zob. tab. 1), a siedziba znajdowała się w Paryżu. ESRO składała się z szeregu ośrodków skupiających się na różnych aspektach działalności organizacji:

- ESTEC (European Space Research and Technology Centre) - instytut inżynierii kosmicznej (Noordwijk, Holandia),

- ESLAB - ośrodek budowy aparatury badawczej i koordynacji projektów rakiet badawczych (również w Noordwijk), początkowo samodzielny, od 1966 r. połączony z ESTEC,

- ESRANGE (Esrange Space Center) - poligon rakietowy dla rakiet badawczych (Kiruna, północna Szwecja),

- ESOC (European Space Operations Centre) - centrum kontroli, śledzenia (sieć ESTRACK) i przetwarzania danych (ośrodek ESDAC) z satelitów organizacji (Darmstadt, Niemcy),

- ESRIN (European Space Research Institute/ESA Centre for Earth Observation) - instytut badawczy, założony w 1966 r. (pierwotnie pod nazwą ESLAR), zajmujący się fizyką przestrzeni kosmicznej, a także centrum obserwacji Ziemi i centrum teleinformatyczne ESA (Frascati pod Rzymem).

Obecnie wszystkie te ośrodki wchodzą w skład Europejskiej Agencji Kosmicznej.

3 Ostatnią próbą była konstrukcja rakiety czterostopniowej - „Europa II” w 1971 r. 


\section{Powstanie ESA i czlonkostwo w tej agencji}

W 1974 r. ELDO i ESRO zostały połączone w Europejską Agencję Kosmiczną (European Space Agency, ESA), która rozpoczęła działalność 30 maja 1975 r. Wprawdzie konwencja, na mocy której powołano ESA, weszła w życie dopiero 30 października 1980 r. - uznano jednak, że Agencja może rozpocząć działalność wcześniej. ESA jest organizacją międzynarodową, której celem jest eksploracja i wykorzystanie przestrzeni kosmicznej, a wymienione powyżej placówki - stały się jej elementami. Przez ponad 4 dekady działalność ESA stała się synonimem europejskiej aktywności w przestrzeni kosmicznej, a po rozpadzie ZSRR Agencja aspirowała do statusu drugiego (po amerykańskiej NASA) aktora działalności kosmicznej na świecie (Spagnulo, Fleeter, i in., 2013, s. 76-83).

Siedziba ESA znajduje się w Paryżu, a ośrodki badawcze „odziedziczyła” ona po ESRO. Dodano do nich następujące agendy:

- Kosmodrom Kourou w Gujanie Francuskiej, gdzie znajduje się Gujański Ośrodek Kosmiczny (Guiana Space Centre) - wykorzystywany przez ESA od 1975 r.,

- Ośrodek szkolenia astronautów EAC (European Astronauts Centre), powołany w 1990 r., z siedzibą w niemieckiej Kolonii,

- Europejskie Centrum Astronomii Kosmicznej (European Space Astronomy Centre, ESAC), działające od 1991 r. w Villafranca pod Madrytem. Od 2005 r. ESAC korzysta z systemu anten badających głęboką przestrzeń kosmiczną,

- Europejskie Centrum Wykorzystania Przestrzeni Kosmicznej i Telekomunikacji (European Centre for Space Applications and Telecommunications, ECSAT), powołane w 2009 r., z siedzibą w brytyjskim Harwell/Oxford.

Do ESA stopniowo wstępowały państwa członkowskie WE (następnie UE) i kraje pozaunijne. Kandydaci do ESA muszą przejść następujące etapy:

- podpisanie z ESA Umowy o Wspótpracy (ang. Cooperation Agreement). Umowa taka daje status członka stowarzyszonego. Korzysta z niego Kanada (od 1979 r.), Turcja (od 2004 r.), Ukraina (od 2008 r.), Izrael (od 2011 r.), Malta (od 2012 r.) i Chorwacja (od 2018 r.). Przedstawiciele tych krajów biorą udział w podejmowaniu decyzji przez ESA, a firmy mogą otrzymywać kontrakty na realizację programów kosmicznych;

- podpisanie Porozumienia o Europejskim Państwie Wspótpracujacym (ang. European Cooperating State Agreement - ECSA). Na tym etapie są relacje z ESA: Litwy (od 2014 r.), Bułgarii i Słowacji (od 2015 r.) oraz Cypru (od 2016 r.);

- uczestnictwo (także finansowe) w pięcioletnim Planie dla Europejskich Państw Wspótpracujacych (ang. Plan for European Cooperating State, PECS), który ma przygotować je do członkostwa w ESA. Firmy z państw-sygnatariuszy PECS mogą brać udział w programach kosmicznych ESA (do wysokości składki wnoszonej przez dane państwo). Taki status ma obecnie Łotwa (od 2015 r.);

- rozpoczęcie negocjacji o przystąpieniu do ESA bądź stowarzyszeniu.

Polska podpisała PECS 27 kwietnia $2007 \mathrm{r}$. Umowa została ratyfikowana rok później - 28 kwietnia 2008 r., nadzór nad wdrażaniem porozumienia sprawowało Ministerstwo Gospodarki, a pełnym członkiem ESA staliśmy się 19 listopada $2012 \mathrm{r}$. 
Skład członkowski ELDO, ESRO i ESA (alfabetycznie)

\begin{tabular}{|l|c|c|c|}
\hline & ELDO & ESRO & ESA \\
\hline Australia* & 1962 & & 1986 \\
\hline Austria & & & 1978 \\
\hline Belgia & 1962 & 1964 & 2008 \\
\hline Czechy & & & 1977 \\
\hline Dania & & 1964 & 2015 \\
\hline Estonia & & & 1995 \\
\hline Finlandia & 1961 & 1964 & 1980 \\
\hline Francja & & & 2005 \\
\hline Grecja & & 1964 & 1979 \\
\hline Hiszpania & 1962 & 1964 & 1979 \\
\hline Holandia & & & 1980 \\
\hline Irlandia & & & 1979 \\
\hline Kanada** & & & 2005 \\
\hline Luksemburg & 1962 & & 1977 \\
\hline Niemcy (RFN) & & & 1986 \\
\hline Norwegia & & & 2012 \\
\hline Polska & & & 2000 \\
\hline Portugalia & & 1964 & 2016 \\
\hline Rumunia & & 1964 & 1976 \\
\hline Słowenia & & 1964 & 2015 \\
\hline Szwajcaria & & & 1978 \\
\hline Szwecja & & & \\
\hline Węgry & 1961 & & 1978 \\
\hline Wielka Brytania & 1962 & & \\
\hline Włochy & & & \\
\hline \hline
\end{tabular}

* Członek stowarzyszony - udostępnił poligon rakietowy.

** Państwo współpracujące.

Wzrost znaczenia ESA nastąpił w połowie lat 80-tych, po tym gdy w 1983 r. prezydent USA R. Reagan zaczął forsować koncepcję Inicjatywy Obrony Strategicznej (Strategic Defence Initiative, SDI), potocznie zwanej „Gwiezdnymi Wojnami”. Program SDI budził w Europie Zachodniej dużą rezerwę, a 4 kwietnia 1985 r. Francuzi przedstawili alternatywę - dedykowany Europejczykom (przede wszystkim Niemcom) program „Eureka”. Miał to być plan cywilnego badania przestrzeni kosmicznej, formalnie niekolidujący z amerykańskim - ale państwa, które chciały się do niego przyłączyć, były przez Francuzów zniechęcane do udziału w SDI. Początek programu ogłoszono 17 lipca 1985 r., a 6 listopada przyjęto tzw. deklarację z Hanoweru, dotyczącą jego pierwszych celów4.

Należy zauważyć, że ESA nie zastępowała, ani nawet nie była w stanie ostatecznie podporządkować sobie programów kosmicznych poszczególnych państw. Stanowiła dla nich forum współpracy, platformę koordynowania ich działań - ale jeśli narodowa agencja kosmiczna postanawiała działać samodzielnie, lub też obok ESA - mogła

${ }^{4}$ Program ewoluował ze stricte kosmicznego do badań wysokich technologii sensu largo i wśród jego celów pojawiły się np. projekty telewizji wysokiej rozdzielczości HDTV czy automatycznie kierowanych samochodów. 
to zrobićs. Z drugiej strony, jeśli część państw ESA chciała partycypować w jakimś przedsięwzięciu, a inne nie - ESA też nie mogła nikogo subordynować ani do udziału, ani też do jego zaniechania.

Katalizatorem budowy unijnego potencjału kosmicznego była Wojna o Kuwejt w latach 1990-1991. Wykazała ona, że państwa zachodnioeuropejskie, które podczas zimnej wojny skupiły się na obronie własnego terytorium przed zagrożeniem ze Wschodu - mają bardzo skromne zdolności do udziału w konfliktach pozaeuropejskich (zdecydowanie ustępują w tej mierze Amerykanom). Widać to było zwłaszcza w ilości wykorzystanych w Wojnie o Kuwejt satelitów: USA miały ich ok. 60 (zwiadowczych, meteorologicznych i innych), Europa - 2. Zarazem działalność ESA nie przewidywała jej „militaryzacji”.

Sytuację tą postanowiła zmienić Unia Zachodnioeuropejska - UZE (Western European Union, WEU), istniejąca od 1948 do 2011 r., która w latach 90-tych aspirowała do roli „zbrojnego ramienia” UE. I tak 27 czerwca 1991 r. jej Rada Ministrów (RM UZE) w Vianden postanowiła utworzyć Centrum Satelitarne UZE (WEU Satellite Centre). Powstało ono 28 kwietnia 1993 r. w Torrejon pod Madrytem, a RM UZE w Lizbonie 15 maja 1995 r. uznała je za stały organ tej organizacji. Jednak pięć lat później (15-16 maja 2000 r. w Porto) RM UZE postanowiła, że stworzony potencjał przekaże się po prostu pod bezpośrednią kontrolę $\mathrm{UE}^{6}$. Centrum Satelitarne przekazano pod kontrolę UE mocą decyzji RM UZE w Marsylii z 13 listopada 2000 r. (przekazanie nastąpiło 1 stycznia 2002 r. $)^{7}$.

Do zadań Centrum należy m.in. wspieranie misji z zakresu: pomocy humanitarnej, opieki nad ludnością cywilną i rozdzielania stron walczących na obszarach kryzysowych, a także stała obserwacja obszarów zagrożonych. Od 1997 r. Centrum dostarczało państwom europejskim informacji m.in. o sytuacji w rejonie Wielkich Jezior (Afryka Równikowa), w Albanii i Kosowie. Centrum korzystało z usług satelitów zarówno europejskich, jak i z innych państw, a eksploatowało kosmodrom Kourou w Gujanie Francuskiej ${ }^{8}$.

\section{Potencjal ESA na tle konkurentów}

Podczas powstawania ESA podkreślano, iż ma ona odmienną hierarchię zadań niż analogiczne agencje USA i ZSRR. „Podbój kosmosu” w wykonaniu supermocarstw miał przybierać charakter konfrontacji i być elementem ich globalnego wyścigu zbrojeń. Wprawdzie ani przestrzeni kosmicznej, ani ciał niebieskich nie można było wykorzy-

${ }^{5}$ Włochy wzięły udział w misji „Cassini-Huygens”, a sami Francuzi uczestniczyli w radzieckim programie kosmicznym „Interkosmos” (zob. niżej).

6 WEU Ministerial Meetings in Porto on 15 \& 16 May 2000, Porto Declaration.

${ }^{7}$ Defence equipment for European crisis management - reply to the annual report of the Council - Document C/1760, 6 Nov. 2001, http://www.assemblee-ueo.org/en/documents/sessions_ordinaires/rpt/2001/1760.html, punkt 21, 41-42.

${ }^{8}$ Pierwszego satelitę UZE (Helios 1A) wystrzelono 7 lipca 1995 r., a drugiego (Helios 1B) 3 grudnia 1999 r., oprócz tego - cała seria jednostek francuskich (satelity Spot 1, 2, 4). Centrum satelitarne korzystało też z danych zakupywanych od innych państw - m.in. amerykańskich (satelity Landsat 4, 5 i 6, Ikonos), kanadyjskich (Radarsat), indyjskich (IRS 1C i D) i rosyjskich. 
stywać dla celów militarnych ${ }^{9}$ - ale technologie opracowywane na potrzeby misji kosmicznych z powodzeniem sprawdzały się w przemyśle zbrojeniowym, a sam wyścig kosmiczny miał charakter prestiżowego pojedynku między Amerykanami a Sowietami. Tymczasem ESA miała swoje wysiłki poświęcać wartościom ogólnoludzkim, takim jak pokojowe badania naukowe, czy rozwój gospodarczy (Zubrin, 2003, s. 65-68).

Możliwości, jakimi dysponowały państwa europejskie nie pozwalały im na nazbyt ambitne samodzielne projekty, ale czyniły z nich atrakcyjnego partnera dla programów kosmicznych podejmowanych przez inne mocarstwa (głównie USA i ZSRR/Rosję). I tak np. pierwsze misje europejskich kosmonautów odbywały się na amerykańskich promach kosmicznych, a dotyczyły eksperymentów w laboratorium kosmicznym Spacelab, budowanym od 1974 r. wspólnie przez NASA i ESRO/ESA.

Należy zauważyć, że państwa Europy Zachodniej prowadziły swoje badania kosmiczne często w lepszej współpracy z ZSRR - niż z USA. Sowieckie sondy ,armady Halleya" (zob. niżej) wykorzystywały urządzenia produkcji francuskiej i zachodnioniemieckiej, z kolei w sowieckim programie międzynarodowych wypraw kosmicznych „Interkosmos" w 1982 r. i w 1988 r. brał udział francuski kosmonauta Jean-Loup Chretien ${ }^{10}$.

Po rozpadzie ZSRR przez kilka lat wydawać się mogło, że ESA pozostanie jedyną konkurentką amerykańskiej NASA. Relatywnie szybko jednak okazało się, że:

- Amerykanie wydają na swoje programy kosmiczne nadal kilka razy więcej niż Europejczycy i zachowują niekwestionowaną dominację w tym obszarze;

- Rosjanie, po kilkuletnim załamaniu posowieckich programów kosmicznych powracają do wyścigu w eksploracji kosmosu ${ }^{11}$;

- kolejnym znaczącym graczem stają się w tej rywalizacji Chiny ${ }^{12}$.

Pamiętać należy jednak, że europejskie (unijne) wydatki na badanie przestrzeni kosmicznej są relatywnie niewielkie, jeśli zestawić je z unijnym PKB - i podobne porównanie zastosować wobec innych liczących się w badaniu kosmosu aktorów. I tak w latach 2012-2014 wydatki na badanie przestrzeni kosmicznej wyniosły dla UE ok. $0,06 \%$ PKB, podobny odsetek wydawała Japonia, a także Chiny (oficjalnie - 0,030,04\%), natomiast USA - 3-4-krotnie większy odsetek swojego PKB (0,2-0,23\%), a Rosja - ekstremalnie wysoki, bo ok. $0,45 \%$ własnego PKB $^{13}$.

Dodatkowo czołowe państwa europejskie prowadzą własne programy kosmiczne, finansując je kwotami porównywalnymi z budżetem ESA. I tak w 2017 r. francuska

${ }^{9}$ Układ o zakazie prób broni nuklearnej $w$ atmosferze, $w$ przestrzeni kosmicznej i pod woda, podpisany w Moskwie 5 sierpnia 1963 r. i Uktad o zasadach działalności państw w zakresie badań i użytkowania przestrzeni kosmicznej łącznie z Księżycem i innymi ciałami niebieskimi, podpisany w Londynie, Moskwie i Waszyngtonie 27 stycznia 1967 r.

${ }^{10}$ Dzięki temu Jean-Loup Chretien stał się pierwszym zachodnioeuropejskim (i francuskim) kosmonautą. W ramach tegoż programu „Interkosmos” w 1978 r. odbył swą podróż jedyny polski kosmonauta - Mirosław Hermaszewski.

${ }^{11}$ Dnem posowieckiego załamania w sferze programów kosmicznych wydają się lata 20012002: wtedy to na Ziemię spadł z orbity wysłużony wrak załogowej stacji kosmicznej „Mir” (23 marca 2001 r.), zaś zamieć śnieżna na kosmodromie w Kazachstanie zniszczyła jedyny posowiecki wahadłowiec „Buran” (12 maja 2002 r.).

12 Pierwszy bezzałogowy pojazd kosmiczny Chiny odpaliły 19 listopada 1999 r. (program Shenzhou), a pierwszy Chińczyk (,taikonauta”) znalazł się w przestrzeni kosmicznej 15 października $2003 \mathrm{r}$.

${ }^{13} \mathrm{https} / / /$ www.esa.int/spaceinimages/Images/2016/03/Space_budget_on_GDP_in_2012_2013_2014. 
CNES otrzymała 2,33 mld €, niemiecka DLR - 2,25 mld €, a włoska ASI - 1,6 mld € (Spagnulo, Fleeter, i in., 2013, s. 8-10).

Tabela 2

PKB wybranych państw i UE w latach 2010-2016

\begin{tabular}{||c|c|c|c|c|c|}
\hline \hline MId USD & UE & USA & Rosja & Chiny & Japonia \\
\hline 2010 & 16,99 & 14,96 & 1,52 & 6,1 & 5,70 \\
\hline 2016 & 18,30 & 16,92 & 1,65 & 9,5 & 6,05 \\
\hline 2019 & 19,41 & 18,30 & 1,76 & 11,5 & 6,20 \\
\hline
\end{tabular}

Źródło: Opracowanie własne na podstawie danych Banku Światowego GDP (constant 2010 US\$) | Data (worldbank.org), https://data.worldbank.org/indicator/NY.GDP.MKTP.KD?end=2016\&start=1960, 19.09.2020.

Obecnie istnieje ok. 80 agencji kosmicznych: narodowych i wielonarodowych ${ }^{14}$. Uznaje się jednak, że tylko kilka z nich miałoby potencjał adekwatny dla konkurowania czy też efektywnej współpracy z ESA. Należałyby do nich:

- amerykańska NASA (National Aeronautics and Space Administration), powołana w 1958 r.;

- rosyjski ROSKOSMOS, powołany w 1992 r., będący kontynuatorem sowieckiego programu kosmicznego powstałego ok. 1955 r.;

- chińska CNSA (China National Space Administration), powołana w 1993 r.;

- japońska JAXA (Japan Aerospace Exploration Agency), powołana w 2003 r.

Tabela 3

Wydatki na badanie kosmosu (kwoty nominalne w mld z podaniem waluty)

\begin{tabular}{||c|c|c|c|c|c||}
\hline & ESA & NASA & ROSKOSMOS & CNSA** $^{* *}$ & JAXA*** $^{*}$ \\
\hline 2010 & $3,74 €$ & $18,72 \$$ & $2,80 \$$ & $2,1 \$$ & $186,6 ¥ / 1,78 \$$ \\
\hline 2011 & $4,00 €$ & $18,45 \$$ & $3,80 \$$ & $2,5 \$$ & $183,4 ¥ / 1,75 \$$ \\
\hline 2012 & $4,02 €$ & $17,77 \$$ & $5,20 \$$ & $3,1 \$$ & $185,4 ¥ / 1,77 \$$ \\
\hline 2013 & $4,28 €$ & $16,86 \$$ & $5,60 \$$ & $3,5 \$$ & $211,1 ¥ / 2,03 \$$ \\
\hline 2014 & $4,10 €$ & $17,65 \$$ & $5,50 \$$ & & $181,5 ¥ / 1,73 \$$ \\
\hline 2015 & $4,43 €$ & $18,01 \$$ & $3,27 \$ *$ & & $154,1 ¥ / 1,47 \$$ \\
\hline 2016 & $5,25 €$ & $19,30 \$$ & \multirow{2}{*}{$\begin{array}{c}\text { Budżet } 2016-2025: 1521 \\
\text { bln. rubli } / 22,5 \mathrm{mld} \$\end{array}$} & $6,0 \$$ & $154,1 ¥ / 1,47 \$$ \\
\hline 2017 & $5,75 €$ & $19,51 \$$ & & $153,7 ¥ / 1,46 \$$ \\
\hline 2018 & $5,60 €$ & $19,10 \$$ & & $5,8 \$$ & $154,0 ¥ / 1,47 \$$ \\
\hline
\end{tabular}

* Zmniejszenie budżetu w 2014 r. spowodowane spadkiem kursu rubla wskutek wojny na Ukrainie i sankcji gospodarczych.

** Dane szacunkowe, oficjalne dane (ok. 0,5 mld USD rocznie) są niewiarygodnie niskie. Duże znaczenie mają też o wiele niższe koszty produkcji.

*** Zastosowano umowny przelicznik 1 USD = 105 JPY.

Źródło: Opracowanie własne na podstawie m.in.: http://sites.nationalacademies.org/cs/groups/ssbsite/documents/webpage/ssb_087080.pdf; https://en.wikipedia.org/wiki/List_of_government_space_agencies; https:// themoscowtimes.com/articles/roscosmos-10-year-budget-cut-for-third-time-51016; http://global.jaxa.jp/about/president/presslec/201401.html; -/201501.html; -/201601.html; -/201701.html; https://www.reddit.com/r/ space/comments/zzgah/nasa_vs_roscosmos_funding_in_billion_usd_2009_to/; https://www.theguardian. com/science/2016/aug/28/china-new-space-superpower-lunar-mars-missions; Japan: JAXA budget 2020 | Statista; M. Aliberti, When China Goes to the Moon..., ,Studies in Space Policy” 11, Springer International Publishing Switzerland 2015 ,Chapter 2: China's Space Programme: An Overview, s. 25, 20.09.2020.

${ }^{14} \mathrm{Z}$ jednej strony istnieją np. dwie agencje kosmiczne ONZ: UNOOSA i UNCOPPUOS, czy też trzy międzynarodowe agencje rejonu Azji i Pacyfiku. Z drugiej - np. Argentyna, Korea Północna, ale też USA powołały po dwie agencje narodowe. 
Znacząca dysproporcja $w$ angażowanych zasobach pomiędzy ESA a NASA pokazuje, że Europejczycy nie są porównywalnie silnym jak Amerykanie aktorem w przestrzeni kosmicznej. Same wydatki lokują ESA na ,solidnej” drugiej pozycji - trzykrotnie słabszej niż Amerykanie, ale znacząco silniejszej niż Rosjanie, Chińczycy czy Japończycy. Jednak Rosjanie rekompensują słabość swoich zasobów materialnych - kolosalnym doświadczeniem i praktyką, podważając ową „drugą pozycję” Europejczyków. Szczególną dysproporcję potencjałów kosmicznych pokazuje poniższe zestawienie narodowości załóg ISS (o samej stacji - niżej): dla ESA liczonej jako całość, porównywalnym partnerem w liczbie wysłanych na ISS kosmonautów nie jest USA czy Rosja - ale Japonia (Ryzenko, 2010, s. 82).

Tabela 4

Narodowości kosmonautów na dyżurach w ISS (61 zmian od października 2000 r. do lutego 2020 r.)

\begin{tabular}{|c|c|c|}
\hline Państwo (alfabetycznie) & „Osobozmiany"* & Kosmonauci* \\
\hline Belgia (ESA) & 2 & 1 \\
\hline Francja (ESA) & 3 & 2 \\
\hline Japonia & 18 & 7 \\
\hline Kanada & 7 & 3 \\
\hline Niemcy (ESA) & 6 & 3 \\
\hline Rosja & 131 & 45 \\
\hline USA & 121 & 61 \\
\hline Wielka Brytania (ESA) & 2 & 1 \\
\hline Włochy (ESA) & 10 & 4 \\
\hline Ogólem & 300 & 127 \\
\hline W tym czlonkowie ESA & 23 (7,67\% ogólnej liczby) & 11 (8,66\% ogólnej liczby) \\
\hline
\end{tabular}

* W zestawieniu tym np. pojedynczy kosmonauta, który dwukrotnie odbył podwójną zmianę - jest liczony za „4 osobozmiany”.

Źródło: Opracowanie własne, na podstawie Lista ekspedycji na Międzynarodowa Stację Kosmiczna - Wikipedia, wolna encyklopedia, 10.09.2020.

Największą rolę w rozwijaniu europejskiego potencjału kosmicznego od dawna odgrywa Francja. Od 1968 r. działa kosmodrom Kourou w Gujanie Francuskiej, Francja również budowała kolejne generacje rakiet nośnych („Veronique”, „Diamant”, „Europa”), a w $1973 \mathrm{r}$. zaczęła rozwijać rakiety rodziny „Ariane” - pierwsza z nich wystartowała z Kourou 24 grudnia 1979 r..$^{15}$ Pierwsza generacja rakiet „Ariane” miała wynosić na orbitę jednocześnie dwa satelity telekomunikacyjne, redukując koszty takich operacji. Obecnie UE korzysta głównie z kolejnych generacji rakiet „Ariane”: rakiety „Ariane 4” w latach 1988-2003 startowały 116 razy (z tego tylko 3 starty były nieudane), a rakiety „Ariane 5” w latach 1996-2018 startowały 104 razy (z tego 2 starty się nie powiodły).

\section{Dochody i wydatki ESA}

Jak zaznaczono wyżej, wydatki państw europejskich na ESA nie są ich jedynymi zasobami przeznaczanymi na badania kosmiczne, gdyż silniejsze państwa europejskie z powodzeniem rozwijają własne, narodowe programy kosmiczne (Badurska, 2010, s. 161-168).

${ }^{15}$ Nazwa jest swoistą grą słów: w j. francuskim oznacza zarówno Ariadnę z greckiej mitologii, jak i ptaka z rodziny kolibrów. 
Struktura dochodów ESA w latach 2010-2019

(źródła dochodów w mln $€$ i w udziale procentowym w budżecie)

\begin{tabular}{|c|c|c|c|c|c|c|c|c|c|c|}
\hline & 2010 & 2011 & 2012 & 22013 & 2014 & 2015 & 2016 & 2017 & 2018 & 2019 \\
\hline $\begin{array}{l}\text { Wpłaty krajów } \\
\text { członkowskich } \\
\text { i Kanady }\end{array}$ & $\begin{array}{l}2778,6 \\
(74,2 \%)\end{array}$ & $\begin{array}{c}2975 \\
(74,5 \%)\end{array}$ & $\begin{array}{c}2653,5 \\
(66 \%)\end{array}$ & $\begin{array}{l}3109,5 \\
(72,6 \%)\end{array}$ & \begin{tabular}{|l|}
3339,3 \\
$(81,4 \%)$
\end{tabular} & $\begin{array}{l}3241,2 \\
(73,1 \%)\end{array}$ & $\begin{array}{c}3740 \\
(71,3 \%)\end{array}$ & $\begin{array}{c}3780 \\
(65,7 \%)\end{array}$ & $\begin{array}{c}3980 \\
(71,1 \%)\end{array}$ & \begin{tabular}{|c|}
4180 \\
$(73,1 \%)$
\end{tabular} \\
\hline $\begin{array}{l}\text { Wpłaty z budże- } \\
\text { tu UE }\end{array}$ & $\begin{array}{c}754,8 \\
(20,2 \%)\end{array}$ & $\begin{array}{c}777,9 \\
(19,5 \%)\end{array}$ & $\begin{array}{c}867,7 \\
(21,6 \%)\end{array}$ & $\begin{array}{c}911,1 \\
(21,3 \%)\end{array}$ & \begin{tabular}{|c|}
623,9 \\
$(15,2 \%)$
\end{tabular} & $\begin{array}{l}1030,5 \\
(23,2 \%)\end{array}$ & $\begin{array}{l}1324,8 \\
(25,2 \%)\end{array}$ & \begin{tabular}{|l|}
1697,9 \\
$(29,5 \%)$
\end{tabular} & \begin{tabular}{|c|}
1314,9 \\
$(23,5 \%)$
\end{tabular} & \begin{tabular}{|l|}
1249,7 \\
$(21,8 \%)$
\end{tabular} \\
\hline $\begin{array}{l}\text { Wpłaty } \\
\text { z ECSA* }\end{array}$ & $\begin{array}{c}5,2 \\
(0,1 \%)\end{array}$ & $\begin{array}{c}7,9 \\
(0,2 \%)\end{array}$ & $\begin{array}{l}252,3 \\
(6,3 \%)\end{array}$ & $\begin{array}{c}4,6 \\
(0,1 \%)\end{array}$ & & & & & & \\
\hline $\begin{array}{l}\text { Wpłaty z Eu- } \\
\text { metsat }\end{array}$ & & & & & \begin{tabular}{c|}
75 \\
$(1,8 \%)$
\end{tabular} & \begin{tabular}{|c|}
122,4 \\
$(2,8 \%)$
\end{tabular} & \begin{tabular}{|l|}
147,9 \\
$(2,8 \%)$
\end{tabular} & \begin{tabular}{|c|}
182,7 \\
$(3,2 \%)$
\end{tabular} & \begin{tabular}{|c|}
221,1 \\
$(3,9 \%)$
\end{tabular} & \begin{tabular}{|c|}
187,2 \\
$(3,3 \%)$
\end{tabular} \\
\hline Inne przychody & $\begin{array}{c}206,1 \\
(5,5 \%)\end{array}$ & $\begin{array}{c}233 \\
(5,8 \%)\end{array}$ & $\begin{array}{l}246,5 \\
(6,1 \%)\end{array}$ & $\begin{array}{c}256,8 \\
(6 \%)\end{array}$ & \begin{tabular}{|c|}
63,8 \\
$(1,6 \%)$
\end{tabular} & $\begin{array}{c}38,8 \\
(0,9 \%)\end{array}$ & $\begin{array}{c}35,6 \\
(0,7 \%)\end{array}$ & $\begin{array}{c}90,7 \\
(1,6 \%)\end{array}$ & $\begin{array}{c}88,5 \\
(1,6 \%)\end{array}$ & \begin{tabular}{|c|}
99,5 \\
$(1,7 \%)$
\end{tabular} \\
\hline Ogólem & 3744,7 & 3993,8 & 4020,1 & 4282,1 & 4102,1 & 4432,9 & 5250 & 5750 & 5600 & 5720 \\
\hline
\end{tabular}

* ECSA - European Cooperating States.

Źródło: Opracowanie własne na podstawie: https://esamultimedia.esa.int/multimedia/DG/ESA_2010_ Budget.pdf; http://www.parabolicarc.com/2013/02/26/esa-faces-the-limits-of-expansion-growing-powerof-eu/; https://www.esa.int/spaceinimages/Images/2015/01/ESA_Budget_2015; https://www.esa.int/spaceinimages/Images/2016/01/ESA_budget_2016; ESA - ESA budget 2018, 20.09.2020.

Analizując ewolucję przychodów do budżetu ESA w latach 2010-2019 można zauważyć:

- jego powolny i niekonsekwentny wzrost do roku 2013, wręcz znaczącą redukcję w roku 2014 (którą można tłumaczyć kryzysem finansowym UE, a w szczególności - krajów strefy waluty euro), następnie szybki rozrost w latach 2016-2017 (o ok. 40\% w dwa lata), a w ostatnich latach - stabilizację na wyższym poziomie;

- dwukrotne redukcje budżetu ESA w latach 2014 i 2018 w porównaniu do lat poprzednich, wiążą się w obu wypadkach ze spadkiem dofinansowania z budżetu UE, a także zmniejszeniem pozycji ,inne przychody". Nie zrekompensował tej redukcji wzrost wpłat z budżetów państw członkowskich (zarówno bezwzględny, jak i procentowy - w 2014 r. jedyny raz powyżej 80\%);

- zniesienie w 2014 r. wpłat (śladowych) od ECSA - grupy państw współpracujących z ESA, zostało od 2015 r. znacząco zrekompensowane znacznymi (ok. $200 \mathrm{mln}$ euro rocznie) wpłatami z Eumetsat - Europejskiej Organizacji Eksploatacji Satelitów Meteorologicznych, istniejącej od 1983 r.;

- znacząco rośnie w budżecie ESA udział wpłat z UE - duża redukcja nastąpiła W momencie najgłębszego kryzysu finansowego strefy euro, kolejne ograniczenie po szczycie z 2017 r. to ostatnie lata.

Tabela 6

Wplaty państw do budżetu ESA w latach 2010-2019 (alfabetycznie, w mln euro, uwzględniono wpłaty pow. 1\% udziału w budżecie oraz wkład Polski)

\begin{tabular}{||c|c|c|c|c|c|c|c|c|c|c||}
\hline & $\mathbf{2 0 1 0}$ & $\mathbf{2 0 1 1}$ & $\mathbf{2 0 1 2}$ & $\mathbf{2 0 1 3}$ & $\mathbf{2 0 1 4}$ & $\mathbf{2 0 1 5}$ & $\mathbf{2 0 1 6}$ & $\mathbf{2 0 1 7}$ & $\mathbf{2 0 1 8}$ & $\mathbf{2 0 1 9}$ \\
\hline 1 & 2 & 3 & 4 & 5 & 6 & 7 & 8 & 9 & 10 & 11 \\
\hline Austria & 50,6 & 54 & 52,2 & 50,1 & 50,2 & 51,5 & 47,6 & 47,1 & 47,4 & 57 \\
& $(1,4 \%)$ & $(1,3 \%)$ & $(1,3 \%)$ & $(1,6 \%)$ & $(1,5 \%)$ & $(1,6 \%)$ & $(1,3 \%)$ & $(1,2 \%)$ & $(1,2 \%)$ & $(1,4 \%)$ \\
\hline
\end{tabular}




\begin{tabular}{||l|c|c|c|c|c|c|c|c|c|c||}
\hline 1 & 2 & 3 & 4 & 5 & 6 & 7 & 8 & 9 & 10 & 11 \\
\hline Belgia & 160 & 164,8 & 169,8 & 187,7 & 188,6 & 189,5 & 188,9 & 206 & 203,4 & 191,4 \\
& $(4,3 \%)$ & $(4,1 \%)$ & $(4,22 \%)$ & $(6 \%)$ & $(5,6 \%)$ & $(5,8 \%)$ & $(5 \%)$ & $(5,5 \%)$ & $(5,1 \%)$ & $(4,6 \%)$ \\
\hline Francja & 681,4 & 751,4 & 718,8 & 747,5 & 754,6 & 718,2 & 844,5 & 855,9 & 961,2 & 1174,4 \\
& $(18,2 \%)$ & $(18,8 \%)$ & $(17,9 \%)$ & $(24 \%)$ & $(22,6 \%)$ & $(22,2 \%)$ & $(22,6 \%)$ & $(22,6 \%)$ & $(24,2 \%)$ & $(28,1 \%)$ \\
\hline Hiszpania & 195,2 & 201,9 & 184 & 149,6 & 139,2 & 131,7 & 152 & 151,2 & 204,9 & 201,8 \\
& $(5,2 \%)$ & $(5,1 \%)$ & $(4,6 \%)$ & $(4,8 \%)$ & $(4,2 \%)$ & $(4,1 \%)$ & $(4,1 \%)$ & $(4 \%)$ & $(5,2 \%)$ & $(4,8 \%)$ \\
\hline Holandia & 95,2 & 84,2 & 60,3 & 79,5 & 125,1 & 74,7 & 102,6 & 72 & 91,1 & 77,7 \\
& $(2,5 \%)$ & $(2,1 \%)$ & $(1,5 \%)$ & $(2,6 \%)$ & $(3,7 \%)$ & $(2,3 \%)$ & $(2,7 \%)$ & $(1,9 \%)$ & $(2,3 \%)$ & $(1,9 \%)$ \\
\hline Niemcy & 625,8 & 713,8 & 750,5 & 772,7 & 765,7 & 797,4 & 872,6 & 858,4 & 920,7 & 927,1 \\
& $(16,7 \%)$ & $(17,9 \%)$ & $(18,7 \%)$ & $(24,8 \%)$ & $(22.9 \%)$ & $(24,6 \%)$ & $(23,3 \%)$ & $(22,7 \%)$ & $(23,1 \%)$ & $(22,2 \%)$ \\
\hline Norwegia & 60,2 & 63,2 & 63,1 & 56,3 & 57,1 & 59,8 & 59,6 & 63,5 & 64 & 64,4 \\
& $(1,6 \%)$ & $(1,6 \%)$ & $(1,6 \%)$ & $(1,8 \%)$ & $(1,7 \%)$ & $(1,8 \%)$ & $(1,6 \%)$ & $(1,7 \%)$ & $(1,6 \%)$ & $(1,5 \%)$ \\
\hline Polska & & & & 28,9 & 28,7 & 30 & 29,9 & 34,6 & 34,6 & 34,6 \\
& & & & $(0,9 \%)$ & $(0,9 \%)$ & $(0,9 \%)$ & $(0,8 \%)$ & $(0,9 \%)$ & $(0,9 \%)$ & $(0,8 \%)$ \\
\hline Rumunia & & & & & & & & & 42,6 & 45,4 \\
& & & & & & & & $(1,1 \%)$ & $(1,1 \%)$ \\
\hline Szwajcaria & 91 & 96,2 & 105,6 & 108,3 & 126,5 & 134,9 & 146,4 & 145,1 & 149,4 & 158,4 \\
& $(2,4 \%)$ & $(2,4 \%)$ & $(2,6 \%)$ & $(3,5 \%)$ & $(3,8 \%)$ & $(4,2 \%)$ & $(3,9 \%)$ & $(3,8 \%)$ & $(3,8 \%)$ & $(3,8 \%)$ \\
\hline Szwecja & 53 & 59,9 & 65,3 & 75 & 94,6 & 80,3 & 73,9 & 72,3 & 72,4 & 74,4 \\
& $(1,4 \%)$ & $(1,5 \%)$ & $(1,6 \%)$ & $(2,4 \%)$ & $(2,8 \%)$ & $(2,5 \%)$ & $(2 \%)$ & $(1,9 \%)$ & $(1,8 \%)$ & $(1,8 \%)$ \\
\hline Wielka & 254,7 & 265,3 & 240 & 300 & 270 & 322,3 & 324,8 & 300 & 334,8 & 369,6 \\
Brytania* & $(6,8 \%)$ & $(6,6 \%)$ & $(6 \%)$ & $(9,6 \%)$ & $(8,1 \%)$ & $(9,9 \%)$ & $(8,7 \%)$ & $(7,9 \%)$ & $(8,4 \%)$ & $(8,8 \%)$ \\
\hline Włochy & 370 & 380 & 350,5 & 400 & 350 & 329,9 & 512 & 550 & 470 & 420,2 \\
& $(9,9 \%)$ & $(9,5 \%)$ & $(8,72 \%)$ & $(12,9 \%)$ & $(10,5 \%)$ & $(10,2 \%)$ & $(13,7 \%)$ & $(14,6 \%)$ & $(11,8 \%)$ & $(10,1 \%)$ \\
\hline
\end{tabular}

* W 2016 r. podjęła decyzję o wystąpieniu z UE.

Źródło: Opracowanie własne na podstawie: https:/esamultimedia.esa.int/multimedia/DG/ESA_2010_Budget.pdf; http://www.esa.int/spaceinimages/Images/2012/01/ESA_budget_by_domain_for_2012_M_Million Euro; http://www.parabolicarc.com/2013/02/26/esa-faces-the-limits-of-expansion-growing-power-of-eu/; http://www.esa.int/spaceinimages/Images/2014/01/ESA_budget_2013; https:/www.esa.int/spaceinimages/ Images/2015/01/ESA_Budget_2015; https://www.esa.int/spaceinimages/Images/2016/01/ESA_budget_2016; http://www.esa.int/spaceinimages/Images/2017/01/ESA_budget_2017; ESA - ESA budget 2018, 20.09.2020.

Jak napisano powyżej, podstawowym źródłem finansowania budżetu ESA są wpłaty państw członkowskich, dające ok. 2/3-3/4 całości wpływu (w 2014 r. było to nawet ponad $80 \%$ ). Analizując listę znaczących płatników (wkłady pow. 1\% budżetu ESA) za lata 2010-2017, można zauważyć że:

- dominują dwa czołowe państwa UE (Francja i Niemcy), przy czym udział ich wpłat w całości budżetu stopniowo rośnie (z 16-18\% do 23-24\% dla każdego, Francja osiąga nawet 28\%). Zarazem Niemcy powoli doganiają Francję - dzieje się tak od 2013 r., kiedy to udział obu państw osiągnął ok. 24-24,8\%. Można to thumaczyć lepszą kondycją niemieckiej gospodarki podczas kryzysu finansowego państw strefy euro;

- zaskakująco solidnym płatnikiem ESA są Włochy (znaczący wzrost z ok. 10 do niemal $15 \%$ wkładów), utrzymujące trzecią pozycję w tym rankingu i to pomimo problemów związanych z kryzysem finansowym, którego gospodarka włoska była jedną z najbardziej poszkodowanych ofiar. Natomiast mało zaangażowanym państwem jest Wielka Brytania - jej udział nie przekroczył 10\%, przy czym powodem nie musi tu być kryzys finansowy (Wielka Brytania była nim słabiej dotknięta), ale decyzja polityczna - ograniczone angażowanie się w projekty europejskie, zwieńczone decyzją o wystąpieniu z UE podjętą w połowie 2016 r.; 
- warto odnotować duże zaangażowanie w finansowanie ESA ze strony niewielkiej Belgii - kontrastujące z niemal dwukrotnie mniejszym wkładem sąsiedniej, większej Holandii, a przekraczające nawet płatności ze strony znacznie większej Hiszpanii;

- słabo w tym rankingu plasuje się Polska - wytwarzając ok. 2,85\% unijnego PKB, nie wpłacamy nawet $1 \%$ budżetu ESA. Zauważyć należy, że Polska, odmiennie niż silniejsze kraje UE - nie prowadzi znaczącego programu kosmicznego. Istniejąca od 2014 r. Polska Agencja Kosmiczna zaczynała z budżetem ok. 10 mln zł, i zatrudniała ok. 50 osób (Naskręt, 2015). Według raportu OCED, w 2013 roku sektor kosmiczny w Polsce wyniósł 46 milionów dolarów - niemal dwukrotnie mniej niż w Austrii (80 mln) (Drabik, 2015). Na lata 2019-2021 na programy kosmiczne Polska przeznaczyła niemal ćwierć miliarda $\mathrm{z}^{16}$.

Tabela 7

Wydatki ESA w latach 2010-2017 (w mln euro)

\begin{tabular}{|c|c|c|c|c|c|c|c|c|}
\hline & 2010 & 2011 & 2012 & 2013 & 2014 & 2015 & 2016 & $\overline{2017}$ \\
\hline $\begin{array}{l}\text { odstawowa działal- } \\
\text { ość }\end{array}$ & & $\begin{array}{c}216,7 \\
(5,4 \%)\end{array}$ & $\begin{array}{c}221,5 \\
(5,5 \%)\end{array}$ & $\begin{array}{c}232,1 \\
(5,4 \%)\end{array}$ & $\begin{array}{c}231,5 \\
(5,6 \%)\end{array}$ & $\begin{array}{c}232,1 \\
(5,2 \%)\end{array}$ & $\begin{array}{c}232,1 \\
(4,4 \%)\end{array}$ & $\begin{array}{c}234,8 \\
(4,1 \%)\end{array}$ \\
\hline Budżet ogólny & $\begin{array}{c}211,4 \\
(5,7 \%)\end{array}$ & $\begin{array}{c}179,9 \\
(4,5 \%)\end{array}$ & & & & & & \\
\hline $\begin{array}{l}\text { Powiązane } \mathrm{z} \text { budże- } \\
\text { tem ogólnym }\end{array}$ & $\begin{array}{c}196,7 \\
(5,3 \%)\end{array}$ & & $\begin{array}{l}190,3 \\
(4,7 \%)\end{array}$ & $\begin{array}{c}206 \\
(4,8 \%)\end{array}$ & $\begin{array}{l}210,8 \\
(5,1 \%)\end{array}$ & $\begin{array}{c}209 \\
(4,7 \%)\end{array}$ & $\begin{array}{l}214,8 \\
(4,1 \%)\end{array}$ & $\begin{array}{l}222,3 \\
(3,9 \%)\end{array}$ \\
\hline Programy naukowe & $\begin{array}{c}409,5 \\
(10,9 \%)\end{array}$ & $\begin{array}{c}464,8 \\
(11,6 \%)\end{array}$ & $\begin{array}{c}479,7 \\
(11,9 \%)\end{array}$ & $\begin{array}{c}507,9 \\
(11,9 \%)\end{array}$ & $\begin{array}{c}506,5 \\
(12,3 \%)\end{array}$ & $\begin{array}{c}507,9 \\
(11,5 \%)\end{array}$ & $\begin{array}{l}507,9 \\
(9,7 \%)\end{array}$ & $\begin{array}{c}513,1 \\
(8,9 \%)\end{array}$ \\
\hline bse & $\begin{array}{c}708,4 \\
(18,9 \%)\end{array}$ & $\begin{array}{c}843,9 \\
(21,1 \%)\end{array}$ & $\begin{array}{c}861,4 \\
(21,4 \%)\end{array}$ & $\begin{array}{c}982,5 \\
(22,9 \%)\end{array}$ & $\begin{array}{c}915,9 \\
(22,3 \%)\end{array}$ & $\begin{array}{c}1254,3 \\
(28,3 \%)\end{array}$ & $\begin{array}{c}1603,5 \\
(30,5 \%)\end{array}$ & $\begin{array}{c}1543,3 \\
(26,9 \%)\end{array}$ \\
\hline Telekomunikacja* & $\begin{array}{c}325,9 \\
(8,7 \%)\end{array}$ & $\begin{array}{c}341,3 \\
(8,5 \%)\end{array}$ & $\begin{array}{c}330 \\
(8,2 \%)\end{array}$ & $\begin{array}{c}314,3 \\
(7,3 \%)\end{array}$ & $\begin{array}{c}325,3 \\
(7,9 \%)\end{array}$ & $\begin{array}{l}309,2 \\
(7 \%)\end{array}$ & $\begin{array}{c}359,3 \\
(6,8 \%) \\
\end{array}$ & $\begin{array}{c}319 \\
(5,6 \%) \\
\end{array}$ \\
\hline Nawiga & $\begin{array}{c}714 \\
(19,1 \%)\end{array}$ & $\begin{array}{c}665,7 \\
(16,7 \%)\end{array}$ & $\begin{array}{c}720,7 \\
(17,9 \%) \\
\end{array}$ & $\begin{array}{c}708,8 \\
(16,6 \%)\end{array}$ & $\begin{array}{c}630,2 \\
(15,4 \%)\end{array}$ & $\begin{array}{l}664,5 \\
(15 \%)\end{array}$ & $\begin{array}{c}609,5 \\
(11,6 \%)\end{array}$ & $\begin{array}{c}1010,8 \\
(17,6 \%)\end{array}$ \\
\hline Loty & $\begin{array}{c}330,4 \\
(8,8 \%)\end{array}$ & $\begin{array}{c}410,9 \\
(10,3 \%)\end{array}$ & $\begin{array}{c}413,3 \\
(10,3 \%)\end{array}$ & $\begin{array}{c}398,6 \\
(9,3 \%)\end{array}$ & $\begin{array}{l}370,9 \\
(9 \%)\end{array}$ & $\begin{array}{c}371,4 \\
(8,4 \%)\end{array}$ & $\begin{array}{l}365,1 \\
(7 \%) \\
\end{array}$ & \multirow[t]{2}{*}{$\begin{array}{c}633 \\
(11 \%)^{* * * *}\end{array}$} \\
\hline $\begin{array}{l}\text { Badania z użyciem } \\
\text { robotów** }\end{array}$ & $\begin{array}{c}102 \\
(2,7 \%)\end{array}$ & $\begin{array}{c}129,4 \\
(3,2 \%)\end{array}$ & $\begin{array}{c}123 \\
(3,1 \%)\end{array}$ & $\begin{array}{c}138,6 \\
(3,2 \%)\end{array}$ & $\begin{array}{c}134,9 \\
(3,3 \%)\end{array}$ & $\begin{array}{c}155,8 \\
(3,4 \%)\end{array}$ & $\begin{array}{l}192,8 \\
(3,7 \%)\end{array}$ & \\
\hline Wystrzeliwanie rakiet & $\begin{array}{c}566,6 \\
(15,1 \%)\end{array}$ & $\begin{array}{c}612,5 \\
(15,3 \%)\end{array}$ & $\begin{array}{c}578 \\
(14,4 \%)\end{array}$ & $\begin{array}{l}684,1 \\
(16 \%)\end{array}$ & $\begin{array}{c}617,4 \\
(15,1 \%)\end{array}$ & $\begin{array}{c}607,7 \\
(13,7 \%)\end{array}$ & $\begin{array}{l}1051,2 \\
(20 \%)\end{array}$ & $\begin{array}{c}1088,4 \\
(18,9 \%)\end{array}$ \\
\hline $\begin{array}{l}\text { Obserwacja sytuacji } \\
\text { w kosmosie }\end{array}$ & $\begin{array}{c}9,9 \\
(0,3 \%)\end{array}$ & $\begin{array}{c}15,7 \\
(0,4 \%)\end{array}$ & $\begin{array}{c}15,4 \\
(0,4 \%)\end{array}$ & $\begin{array}{c}10,1 \\
(0,2 \%)\end{array}$ & $\begin{array}{c}9,1 \\
(0,2 \%)\end{array}$ & $\begin{array}{c}13,9 \\
(0,3 \%)\end{array}$ & $\begin{array}{c}12,9 \\
(0,2 \%)\end{array}$ & $\begin{array}{c}15,1 \\
(0,3 \%)\end{array}$ \\
\hline Technologie*** & $\begin{array}{c}84,8 \\
(2,3 \%)\end{array}$ & $\begin{array}{l}105,1 \\
(2,5 \%)\end{array}$ & $\begin{array}{c}81 \\
(2 \%)\end{array}$ & $\begin{array}{c}94,6 \\
(2,2 \%)\end{array}$ & $\begin{array}{c}146,8 \\
(3,6 \%)\end{array}$ & $\begin{array}{c}105,3 \\
(2,4 \%)\end{array}$ & $\begin{array}{c}99,5 \\
(1,9 \%)\end{array}$ & $\begin{array}{l}114,3 \\
(2 \%)\end{array}$ \\
\hline $\begin{array}{l}\text { Współpraca z krajami } \\
\text { ECSA }\end{array}$ & $\begin{array}{c}5,2 \\
(0,1 \%)\end{array}$ & $\begin{array}{c}7,9 \\
(0,2 \%)\end{array}$ & $\begin{array}{c}5,8 \\
(0,1 \%)\end{array}$ & $\begin{array}{c}4,6 \\
(0,1 \%)\end{array}$ & $\begin{array}{c}2,7 \\
(0,1 \%)\end{array}$ & $\begin{array}{c}2 \\
(0,1 \%)\end{array}$ & $\begin{array}{c}4 \\
(0,1 \%)\end{array}$ & $\begin{array}{c}5,5 \\
(0,1 \%)\end{array}$ \\
\hline Ogółem & 3744,7 & 3993,8 & 4020,1 & 4282,1 & 4102,1 & 4432,9 & 5250 & 5750 \\
\hline
\end{tabular}

W zestawieniu pominięto pojawiający się tylko w $2010 \mathrm{r}$. dział „Mikrograwitacja” (79,9 mln €, 2,1\% budżetu ESA) i pojawiający się tylko w 2017 r. dział „Prodex” (47,2 mln €, 0,8\% budżetu ESA).

* Od 2012 r. pod nazwą: „Telecom \& Integrated Applications”.

** Od 2012 r. pod nazwą: „Robotic Exploration \& Prodex”.

*** Od 2012 r. pod nazwą: ,Technology suport”.

${ }^{16}$ Krajowy program kosmiczny 2019-2021: 54 projekty wspierające rozwój polskiej branży kosmicznej na 3 lata, polsa.gov.pl, 20.09.2020. 
**** W 2017 r. jako wspólna pozycja budżetowa.

Źródło: https://esamultimedia.esa.int/multimedia/DG/ESA_2010_Budget.pdf; http://www.esa.int/spaceinimages/Images/2014/01/ESA_budget_by_domain_for_2013_M_Million_Euro; http://www.esa.int/ spaceinimages/Images/2014/01/ESA_budget_by_domain_for_2014_M_Million_Euro; www.esa.int/ spaceinimages/Images/2016/01/ESA_budget_2016_by_domain; http://www.esa.int/spaceinimages/Images/2017/01/ESA_budget_2017_by_domain.

W budżecie na 2017 r. dwa wcześniej odrębne działy: „loty załogowe” i „,badania z użyciem robotów” połączono w jeden: „Human Spaceflight \& Robotic Exploration”. Zarazem wyodrębniono nowy dział „Prodex”, będący wcześniej częścią działu „Robotic Exploration \& Prodex” - w 2017 r. „Prodex” otrzymał osobny budżet w wysokości $47,2 \mathrm{mln} €(0,8 \%$ ogólnego budżetu ESA). Była to pierwsza zmiana w podziale budżetu ESA od 2011 r. - wtedy skasowano istniejący jeszcze w 2010 r. osobny dział „Mikrograwitacja" (w 2010 r. miał on budżet 79,9 mln €, stanowiący 2,1\% ogólnego budżetu ESA). Analizując ewolucję wydatków z budżetu ESA w latach 2010-2017 można zauważyć:

- potężny (ponad 100\% kwotowo i niemal 50\% udziału w budżecie) wzrost wydatków na obserwację Ziemi;

- znaczący (niemal 100\% kwotowo i niemal 25\% udziału w budżecie) wzrost wydatków na wystrzeliwanie rakiet;

- wzrost kwotowy, aczkolwiek spadek udziału w budżecie pozycji „,kosmiczne programy naukowe" (space science).

\section{Wybrane misje i programy ESA}

\section{Armada Halleya}

W połowie lat 80-tych dogodnym obiektem badań stała się kometa Halleya, kolejny raz zbliżająca się do Słońca i do Ziemi ${ }^{17}$. Dnia 9 lutego 1986 r. przeszła przez swoje peryhelium (minimalna odległość od Słońca, wynoszącą dla tej komety ok. $88 \mathrm{mln} \mathrm{km}$ ), a 15 marca 1986 r. zbliżyła się do Ziemi na minimalną odległość $150 \mathrm{mln} \mathrm{km}$. Ta wyjątkowa okoliczność została wykorzystana przez czołowe mocarstwa kosmiczne do przeprowadzenia serii badań i swoistego „wyścigu”, który miał wykazać kto dokona najdokładniejszych i najbardziej innowacyjnych badań. Wystrzelone na potrzeby tych badań aparaty kosmiczne nazwano „Armadą Halleya” (Halley Armada). I tak Sowieci (we współpracy z Francuzami) wystrzelili sondy „Wega 1” i „Wega 2”, Amerykanie - International Cometary Explorer ${ }^{18}$, Japończycy - sondy „Sakigate” i „Suisei”, a ESA - sondę „Giotto” (wystartowała 2 lipca 1985 r. z kosmodromu Kourou w Gujanie Francuskiej) ${ }^{19}$. Sonda ta była pierwszym obiektem międzyplanetarnym zbudowanym

17 Jej cykl obiegu twa ok. 76 lat, poprzednio obserwowano ją w pobliżu Ziemi w $1910 \mathrm{r}$.

18 „International”, gdyż NASA działała wspólnie z europejską ESA. Sonda została odpalona jeszcze w 1978 r., pierwotnie miała badać wiatr słoneczny, a następnie wykorzystano ją do obserwacji Komety Halleya.

19 Nazwa pochodzi od włoskiego malarza i architekta, Giotto di Bondone (1266-1337), autora fresków w Asyżu, Florencji i Padwie. 
przez ESA. I właśnie „Giotto” dokonała najprecyzyjniejszych badań i fotografii: przelatując 14 marca $1986 \mathrm{r}$. mniej niż $600 \mathrm{~km}$ od komety po raz pierwszy w historii wykonała bezpośrednie zdjęcia jądra kometarnego. „Giotto” była też pierwszą sondą, która powróciła z głębokiej przestrzeni i ponownie zbliżyła się do Ziemi (dnia 2 lipca 1990 r. na odległość 16300 km).

\section{Kosmiczny Teleskop Hubble'a}

Pod koniec lat 70-tych ESA zawarła z amerykańską NASA porozumienie o wspólnej budowie Kosmicznego Teleskopu Hubble' ${ }^{20}$ (Hubble Space Telescope, HST). Dla Amerykanów podstawowym problemem były skokowo rosnące koszty tego projektu - początkowo szacowano je na $400 \mathrm{mln}$ USD, a tymczasem na 1978 r. budżet projektu wyniósł zaledwie $36 \mathrm{mln}$ USD. Ostatecznie samo skonstruowanie teleskopu pochłonęło 2,5 mld USD, a wraz z wyniesieniem go na orbitę i serwisowaniem koszt wyniósł 4,5-6 mld USD ${ }^{21}$. ESA zgodziła się na dofinansowanie projektu równowartością $600 \mathrm{mln}$ ecu - w zamian za udostępnienie europejskim astronomom przynajmniej $15 \%$ czasu obserwacji teleskopu ${ }^{22}$. Teleskop został wyniesiony na orbitę (wysokość ok. 610-620 km) przez prom kosmiczny „Discovery” dnia 20 kwietnia 1990 r., a funkcjonuje od 20 maja tegoż roku. Jako pierwszy teleskop umożliwiający obserwację bez zakłóceń spowodowanych wpływem ziemskiej atmosfery, HST stał się przełomowym urządzeniem poszerzającym możliwości obserwacji astronomicznej.

\section{Misja Cassini-Huygens}

Kolejnym udanym przykładem współpracy pomiędzy NASA a ESA była misja bezzałogowej sondy kosmicznej przeznaczonej do badania Saturna, jego pierścieni i księżyców ${ }^{23}$. Plan ekspedycji NASA i ESA przygotowały w latach 1987/1988, a nadano jej nazwę „Cassini-Huygens"24. Misja ta składała się z dwóch elementów: Amerykanie dostarczyli „Cassini’ego” - orbiter, czyli część sondy, która miała pozostać w przestrzeni kosmicznej (antenę główną dla orbitera dostarczyła włoska ASI, współdziałająca z NASA w ramach umów bilateralnych, z pominięciem ESA), a Eu-

${ }^{20}$ Nazwany na cześć amerykańskiego astronoma Edwina Hubble’a (1889-1953), odkrywcy galaktyk leżących poza Drogą Mleczną.

${ }^{21}$ Koszty wzrosły też wskutek katastrofy promu kosmicznego „Challenger” 28 stycznia 1986 r., co na ponad 2 lata zablokowało program lotów. W ramach cięć kosztów zmniejszono również średnicę zwierciadła teleskopu - z 3 do 2,4 m.

22 "Memorandum of Understanding Between The European Space Agency and The United States National Aeronautics and Space Administration", reprinted in NASA SP-2001-4407: Exploring the Unknown, Chapter 3, Document III-29, p. 671.

${ }^{23}$ Oficjalnie za trzeciego współorganizatora tej misji uważa się Włoską Agencję Kosmiczną (Agenzia Spaziale Italiana, ASI). Można uznać to za kolejny dowód znacznej autonomii narodowych agencji kosmicznych wobec ESA i niezdolności ESA do subordynowania tych instytucji.

${ }^{24}$ Zarówno pochodzący z Włoch, a pracujący we Francji Giovanni Domenico Cassini (16251712), jak i Holender Christiaan Huygens (1629-1695) badali księżyce i pierścienie Saturna. 
ropejczycy „Huygensa” - lądownik (jego głównym wykonawcą była francuska firma Aerospatiale). Podział zadań oddawał prymat w misji Amerykanom.

Sonda została wystrzelona 15 października 1997 r., a w drodze do Saturna dwukrotnie przeleciała obok Wenus, minęła Ziemię oraz Jowisza. W lipcu 2004 r. Cassini stał się pierwszym sztucznym satelitą Saturna, a odłączony od sondy próbnik Huygens 14 stycznia 2005 r. wylądował na powierzchni największego z księżyców Saturna - Tytana, przekazując przez kilka godzin informacje o miejscu lądowania. Natomiast sonda Cassini, która pierwotnie miała zakończyć pracę w 2008 r. po 75 okrążeniach Saturna - wykonała tych okrążeń aż 293, przekazując informacje na Ziemię aż do 15 września 2017 r., kiedy spłonęła w atmosferze Saturna. Dzięki misji Cassini-Huygens odkryto 6 nowych księżyców Saturna, bliżej poznano strukturę jego pierścieni i ich związki z księżycami planety, poznano też wygląd powierzchni Tytana i bezpośrednio zbadano jego atmosferę.

\section{Międzynarodowa Stacja Kosmiczna}

Kolejnym dużym przedsięwzięciem w przestrzeni kosmicznej, w którym istotną rolę odgrywają Europejczycy, jest Międzynarodowa Stacja Kosmiczna (International Space Station, ISS) (Ryzenko, 2010). Pierwsze plany budowy stacji kosmicznej wspólnie przez USA, Japonię, Kanadę i ESA pojawiły się w 1991 r. Rosja, jako państwo mające $\mathrm{w}$ tej dziedzinie największe doświadczenie, ale wciąż ponoszące koszty rozpadu ZSRR, dołączyła do nich w 1993 r., a w 1998 r. - Brazylia. W ten sposób międzynarodowym wysiłkiem miała powstać konstrukcja, zastępująca wcześniejsze projekty stacji orbitalnych: amerykańską „Freedom”, sowiecką „Mir-2” i europejską „Columbus”. ISS miała składać się z modułów, produkowanych stopniowo w poszczególnych krajach i kolejno wynoszonych na orbitę w ramach trzech etapów:

- I (lata 1995-1998) - przygotowanie modułów i międzynarodowe loty do rosyjskiej stacji „Mir”;

- II (lata 1998-2001) - montaż i wstępna eksploatacja;

- III (lata 2001-2011) - dokończenie budowy i dalsza eksploatacja.

Pierwszy element stacji, rosyjski moduł "Zaria” został wysłany w kosmos 20 listopada 1998 r., a po zmontowaniu trzech modułów (dołączono amerykański „Unity” i drugi rosyjski „Zwiezda”), dnia 31 października 2000 r. stację obsadziła stała załoga $^{25}$. Na ogólną liczbę 61 zmian od 31 października 2000 r. do 20 lutego 2020 r. początkowo na ISS przebywały zespoły 3-osobowe. Po katastrofie wahadłowca „Columbia” załogi ISS zredukowano do 2 osób. Od wiosny 2006 r. przywrócono załogi 3-osobowe, ale z przeplatanymi dyżurami (1 osoba z poprzedniego dyżuru zostawała $\mathrm{z}$ następnym i powracała wraz z nim na Ziemię, pozostawiając na ISS kolejnego zmiennika. Od 2011 r. na ISS może przebywać jednocześnie 6 osób z dwóch „przeplatanych" dyżurów (trwających z reguły 155-175 dni; min. 120, max. 200).

Początkowo całkowity budżet programu miał zamknąć się w kwocie 17,4 miliarda USD, lecz do momentu wystrzelenia pierwszego modułu wzrósł już do

${ }^{25}$ Budowę ISS opóźniła katastrofa promu kosmicznego „Columbia” 16 stycznia 2003 r., co ponownie na ponad 2 lata zablokowało loty. 
40 mld USD. Obecnie, przy założeniu że ISS będzie funkcjonować do 2028 r. całkowity koszt jej budowy, konserwacji i utrzymania z nią łączności szacowany jest na ok. 100 mld USD.

ESA dostarczyła kilku modułów (na ogólną liczbę 16):

- „Harmony” (budowa - włoska spółka Alenia Spazio, dołączony do ISS w 2007 r.);

- „Columbus” (moduł laboratoryjny, budowa - EADS SPACE Transportation i Alenia Spazio, dołączony do ISS w 2008 r.);

- „Tranquility” (budowa - francuska spółka Thales Alenia Space, dołączony do ISS w 2010 r.);

- „Cupola” (moduł obserwacyjny, budowa - włoska spółka Alenia Spazio, dołączony do ISS w 2010 r.);

- „Leonardo" (moduł zaopatrzeniowy, budowa - włoska spółka Alenia Spazio, dołączony do ISS w 2010 r.).

Spośród tych 5 modułów jedynie „Columbus” jest w pełni europejską konstrukcją. Pozostałe cztery powstawały w systemie: „europejska budowa/amerykańska obsługa".

Tak jak zaznaczono - rola ESA była w tym programie istotna, lecz kolejny raz Europejczycy byli jedynie podwykonawcami w operacji, której główny cel definiowały inne mocarstwa kosmiczne. Zauważyć też należy, że w projekt ISS zaangażowana była nie cała ESA - a tylko część jej państw członkowskich: Belgia, Dania, Francja, Hiszpania, Holandia, Niemcy, Norwegia, Szwajcaria, Szwecja, Wielka Brytania i Włochy.

\section{Rosetta}

W pierwszych latach XXI w. ESA podjęła niezwykle ambitną i spektakularną operację - badanie jądra przelatującej komety, poprzez wylądowanie na nim próbnika, który pobrałby próbki jądra. Misję tą miała zrealizować sonda „Rosetta”, a do badań wybrano kometę 67P/Czuriumow-Gierasimienko ${ }^{26}$. Misja rozpoczęła się 2 marca 2004 r. wyniesieniem „Rosetty” na orbitę przez francuską rakietę „Ariane 5G+”. Po dekadzie krążenia po Układzie Słonecznym (zbliżenie się do Marsa, obserwacja kilku planetoid) latem 2014 r. „Rosetta” dotarła w pobliże wyznaczonej komety i weszła na orbitę wokół jej jądra. Z pokładu sondy został uwolniony lądownik „Philae”, który 12 listopada $2014 \mathrm{r}$. po raz pierwszy w historii wylądował na powierzchni komety ${ }^{27}$. Po niemal dwóch latach orbitowania wokół jądra komety, 30 września 2016 r. „Rosetta” została zniszczona przez uderzenie $\mathrm{w}$ jej powierzchnię.

Misja Rosetta była misją kluczową w ramach realizowanego przez ESA programu badań kosmicznych Horizon 2000. W jej realizacji z ESA współpracowały narodowe agencje kosmiczne z kilku krajów europejskich oraz NASA. Celem misji było przeprowadzenie badań mających pomóc w poznaniu pochodzenia komet, powiązań mię-

${ }^{26}$ Kometę tą odkryli w 1969 r. sowieccy astronomowie: Klim Czuriumow i Swietłana Gierasimienko. Kometa ta obiega Słońce w niemal 6,5 roku, a jej jądro ma zaledwie 4 km średnicy.

${ }^{27}$ Niestety, problemy z lądowaniem spowodowały, że kontakt „Philae” z „Rosettą” i z Ziemią był bardzo słaby - do 9 lipca 2015 r. lądownik wysłał tylko kilka, krótkich komunikatów. 
dzy materią kometarną i materią międzygwiazdową oraz ich znaczenia dla powstania Układu Słonecznego.

Zarówno „Rosetta” jak i „Philae” były konstruowane przez konsorcja międzynarodowe, aczkolwiek głównymi konstruktorami były firmy niemieckie (Astrium GmBH). Oprócz nich do współpracy zaproszono m.in. Amerykanów, a także ekspertów z Polski i Węgier. Koszty całej misji (od budowy sondy po jej doprowadzenie na orbitę komety) szacuje się na ok. 1,5 mld euro.

\section{Kosmiczne Obserwatorium Herschela i satelita Planck}

Już od wielu lat na orbitę wynoszone są kolejne teleskopy, mające uczynić obserwację kosmosu - bardziej dokładną. ESA podjęła się samodzielnego umieszczenia na orbicie podobnego urządzenia, nazwanego „Kosmicznym Obserwatorium Herschela" ${ }^{28}$. Zbudowano teleskop o średnicy zwierciadła głównego 3,5 m - największej jak dotychczas wśród urządzeń wynoszonych na orbitę. Dnia 14 maja 2009 r. teleskop wystartował na pokładzie francuskiej rakiety „Ariane 5”, a podjął pracę równo w miesiąc później, 14 czerwca. Praca teleskopu zależna była od posiadanych zapasów helu - 29 kwietnia 2013 r. zakończono eksploatację tego urządzenia.

Podobnie jak w innych tego typu misjach budową podzieliły się czołowe państwa ESA. Głównym wykonawcą „Obserwatorium Herschela” było Thales Alenia Space w Cannes. Głównym wykonawcą modułu ładunku było EADS Astrium w Friedrichshafen, moduł serwisowy wykonało Thales Alenia Space w Turynie, a teleskop - EADS Astrium w Tuluzie. Całkowity koszt misji „Herschela” wyniósł około 1 miliarda euro, licząc łącznie koszty budowy satelity, jego instrumentów naukowych, wydatki związane ze startem i nawigacją.

Na pokładzie tej samej rakiety „Ariane 5” 14 maja 2009 r. wyniesiono na orbitę satelitę „Planck” ${ }^{29}$, który zaczął pracę dnia 13 sierpnia tegoż roku. Ponad 4 lata później, 23 października 2013 r. misja „Plancka” została zakończona, a jej efektem było m.in. oszacowanie na podstawie promieniowania wieku Wszechświata na 13,8 mld lat, a ilości w nim tzw. ,ciemnej materii” - na niemal 70\%.

Całkowity koszt misji Planck miał wynieść około 700 milionów euro. Wchodzi w to koszt budowy satelity, jego instrumentów naukowych, koszty startu i operacyjne.

\section{Podsumowanie}

Wzrost budżetu ESA w ostatnich latach napawa optymizmem, jeśli uznać ten wskaźnik za miarę europejskiego zaangażowania w przestrzeni kosmicznej. Można

${ }^{28}$ Nazwa obserwatorium została nadana na cześć rodzeństwa Herschel - Anglików niemieckiego pochodzenia, zajmujących się astronomią: Wilhelm (1738-1822) odkrył planetę Uran, a także istnienie promieniowania podczerwonego; jego siostra Caroline (1750-1848), samodzielnie odkryła 8 komet.

${ }^{29}$ Max Planck (1858-1947) był wybitnym niemieckim fizykiem, twórcą mechaniki kwantowej, laureatem Nagrody Nobla z zakresu fizyki za 1918 r. 
oczekiwać, że wzrost wydatków będzie przekładał się na coraz bardziej ambitne projekty. Jednak potencjału kosmicznego nie kreuje się nawet $\mathrm{z}$ dekady na dekadę - dobrym przykładem są tu Chiny. Obecnie - i zapewne jeszcze przez długie lata - ESA będzie zadowalała się rolą „podwykonawcy” głównie w amerykańskich projektach.

\section{Zagrożenia dla ESA są wielorakie:}

- rozproszenie wysiłków państw członkowskich: równolegle prowadzą one własne programy kosmiczne, często bardzo kosztowne;

- „asymetria” zaangażowania w ESA: finansowe zaangażowanie w ESA pokazuje swoiste „rozwarstwienie” państw członkowskich. Dominują Niemcy i Francja, silną pozycję mają Włochy, relatywnie silną - Belgia, znacznie słabszą niż wynikałoby to $\mathrm{z}$ ich potencjału - Wielka Brytania i Hiszpania, a reszta krajów niemal się nie liczy;

- rozproszenie wysiłków samej UE: od lat 90-tych tworzono kilka struktur mających obsługiwać rozmaite programy kosmiczne: oprócz ESA - także Centrum Satelitarne UZE/UE, czy wreszcie osobny program nawigacji satelitarnej - „Galileo” (Zubrin, 2003).

Ostatnim zagrożeniem jest „pacyfizm” działalności ESA. Niestety, ale jedną z ważniejszych motywacji zaangażowania się czołowych mocarstw (USA, b. ZSRR, Rosji, Chin) w badanie kosmosu jest skorelowanie tych projektów $-\mathrm{z}$ technologiami militarnymi. Hojność wydatków na programy kosmiczne wynikała ze znaczenia tych projektów w wyścigu zbrojeń (d'Antonio, 2012). UE, która z ogromnymi trudnościami tworzy własny potencjał obronny - również z tej przyczyny nie staje się pełnoprawnym aktorem w przestrzeni kosmicznej.

\section{Bibliografia}

Aliberti M. (2015), When China Goes to the Moon..., Studies in Space Policy" 11, Springer International Publishing Switzerland, Chapter 2: China's Space Programme: An Overview, s. 25.

Badurska A. (2010), Europejska polityka kosmiczna - przemyst, rynek, koniunktura, w: Wykorzystanie przestrzeni kosmicznej. Świat-Europa-Polska, red. Z. Galicki, T. Kamiński, K. Myszona-Kostrzewa, Warszawa, s. 161-168.

d'Antonio M. (2012), Wyścig na orbitę, wyd. Prószyński i S-ka, Warszawa.

Defence equipment for European crisis management - reply to the annual report of the Council - Document C/1760, 6 Nov. 2001, http://www.assemblee-ueo.org/en/documents/sessions_ ordinaires/rpt/2001/1760.html.

„Memorandum of Understanding Between The European Space Agency and The United States National Aeronautics and Space Administration", reprinted in NASA SP-2001-4407: Exploring the Unknown, Chapter 3, Document III-29, s. 671.

Ryzenko J. (2010), Międzynarodowa stacja kosmiczna. Przykład wspótpracy międzynarodowej państw w badaniu i eksperymentalnym wykorzystaniu przestrzeni kosmicznej, w: Wykorzystanie przestrzeni kosmicznej. Świat-Europa-Polska, red. Z. Galicki, T. Kamiński, K. Myszona-Kostrzewa, Warszawa, s. 69-83.

Spagnulo M., Fleeter R., i in. (2013), Space Program Management; Methods and Tools, wyd. Springer, New York. 
Układ o zakazie prób broni nuklearnej w atmosferze, w przestrzeni kosmicznej i pod woda, podpisany w Moskwie 5 sierpnia $1963 \mathrm{r}$.

Układ o zasadach działalności państw w zakresie badań i użytkowania przestrzeni kosmicznej łącznie z Księżycem i innymi ciałami niebieskimi, podpisany w Londynie, Moskwie i Waszyngtonie 27 stycznia $1967 \mathrm{r}$.

WEU Ministerial Meetings in Porto on 15 \& 16 May 2000, Porto Declaration.

Zubrin R. (2003), Narodziny cywilizacji kosmicznej, wyd. Prószyński i S-ka, Warszawa.

\section{Netografia}

Drabik P. (2015), Ile zyskamy na Polskiej Agencji Kosmicznej?, 11.03.2015 18:24:07, http://jagiellonski24.pl/2015/03/11/ile-zyskamy-na-polskiej-agencji-kosmicznej/, 26.03.2018.

http://global.jaxa.jp/about/president/presslec/201401.html; -/201501.html; -/201601.html; -/201701. html;

http://sites.nationalacademies.org/cs/groups/ssbsite/documents/webpage/ssb_087080.pdf.

http://www.esa.int/spaceinimages/Images/2012/01/ESA_budget_by_domain_for_2012_M_Million_Euro.

http://www.esa.int/spaceinimages/Images/2014/01/ESA_budget_2013.

http://www.esa.int/spaceinimages/Images/2014/01/ESA_budget_by_domain_for_2013_M_Million_Euro.

http://www.esa.int/spaceinimages/Images/2014/01/ESA_budget_by_domain_for_2014_M_Million_Euro.

http://www.esa.int/spaceinimages/Images/2017/01/ESA_budget_2017, 22.03.2018.

http://www.esa.int/spaceinimages/Images/2017/01/ESA_budget_2017_by_domain.

http://www.parabolicarc.com/2013/02/26/esa-faces-the-limits-of-expansion-growing-power-of-eu/.

https://data.worldbank.org/indicator/NY.GDP.MKTP.KD?end=2016\&start=1960, 26.03.2018.

https://esamultimedia.esa.int/multimedia/DG/ESA_2010_Budget.pdf.

https://themoscowtimes.com/articles/roscosmos-10-year-budget-cut-for-third-time-51016.

https://www.esa.int/spaceinimages/Images/2015/01/ESA_Budget_2015.

https://www.esa.int/spaceinimages/Images/2016/01/ESA_budget_2016, 20.03.2018.

https://www.esa.int/spaceinimages/Images/2016/03/Space_budget_on_GDP_in_2012_2013_2014.

https://www.reddit.com/r/space/comments/zzgah/nasa_vs_roscosmos_funding_in_billion_ usd_2009_to/.

https://www.theguardian.com/science/2016/aug/28/china-new-space-superpower-lunar-mars-missions.

Naskręt M. (2015), 50 etatów w Polskiej Agencji Kosmicznej. Nie musisz być fizykiem, 22 kwietnia 2015, https://www.trojmiasto.pl/wiadomosci/50-etatow-w-Polskiej-Agencji-KosmicznejNie-musisz-byc-fizykiem-n89851.html, 26.03.2018.

www.esa.int/spaceinimages/Images/2016/01/ESA_budget_2016_by_domain.

\section{Streszczenie}

Artykuł poświęcony jest genezie, strukturze i obecnemu potencjałowi Europejskiej Agencji Kosmicznej. Struktura ta konsoliduje projekty państw europejskich, dotyczące badania przestrzeni kosmicznej. W ostatnich latach ESA podejmowała liczne projekty naukowo-badawcze. Mimo potężnego zaplecza, jakim jest europejska gospodarka, ESA ma jednak znacznie mniejsze możliwości niż jej główna konkurentka - amerykańska NASA. Badania 
kosmosu, prowadzone przez ESA często mają charakter uzupełniający i pomocniczy wobec planów NASA. Silnymi konkurentami dla ESA są też agencje kosmiczne innych państw Rosji, Chin czy Japonii.

Słowa kluczowe: Europejska Agencja Kosmiczna, Unia Europejska, kosmos, badania, loty kosmiczne

\section{European Space Agency: ambitious plans, modest possibilities, powerful competitors}

\section{Summary}

The article is devoted to the genesis, structure and present potential of the European Space Agency. This structure consolidates the projects of European countries related to the exploration of space. In recent years, ESA has undertaken numerous scientific and research projects. Despite the powerful base, which is the European economy, ESA has much less opportunities than its main competitor - the American NASA. Space research conducted by ESA is often complementary and auxiliary to NASA's plans. Space agencies from other countries - Russia, China and Japan - are also strong competitors for ESA.

Key words: European Space Agency, European Union, space, research, space flights 
